\title{
Vitamīnu satura izmaiņas pilngraudu rudzu maizes ražošanā Changes in Vitamin Content during the Whole Grain Rye Bread Processing
}

\author{
Vija Ozoliņa*, Daiga Kunkulberga \\ LLU Pārtikas tehnologijas katedra \\ Department of Food Technology, LLU
}

\begin{abstract}
Whole grain rye bread is a historically rich item in Latvian culture, and Latvians are rightly proud of the rye bread tradition they have cultivated. Much international research has shown that regular intake of rye bread positively influences the consumer health. Latvia has a long history of rye bread preparation, but lacks information about changes in vitamin content during the manufacturing process - from the beginning of baking till the end product - bread. The aim of the study was to investigate the changes in vitamin content during the whole grain rye bread production process. The object of the research work: traditional Latvian whole grain rye bread, the dough of which is prepared with scald and natural yeast and then baked in a wood-fired clay oven. AOAC standard methods were used to determine the content of thiamine ( $B_{1}$ vitamin), riboflavin $\left(B_{2}\right.$ vitamin), niacin ( $\mathrm{B}_{3}$ vitamin), and $\alpha$-tocopherol (E vitamin). The content of vitamins was analyzed in whole grain rye flour, leavened rye flour dough, and rye bread baked for 30, 45, 60 and 75 minutes. Bread crust and crumb were analyzed separately. The content of B complex vitamers in whole grain rye flour and bread was determined using LC-MS combined with stable isotope dilution assay. The study showed that whole grain rye bread contains a wide range of B complex vitamins. During the whole grain rye bread processing it was observed that, compared to vitamin content in flour, thiamine content reduced by $36 \%$, but content of riboflavin, niacin and $\alpha$-tocopherol increased by $53 \%, 40 \%$ and $6 \%$ respectively.
\end{abstract}

Key words: Whole grain rye bread, thiamine, riboflavin, niacin, $\alpha$-tocopherol.

\section{Ievads}

Maize ir viens no galvenajiem uztura produktiem, ko lietojam ikdienā, jo tā nodrošina gandrīz divas trešdaļas no dienā nepieciešamā enerǵijas daudzuma. Saskaņā ar senajām latviešu tradīcijām rudzu rupjmaize tiek cepta no kvalitatīviem rudzu rupjajiem miltiem, sāls, cukura un ksimenēm, pievienojot dabīgo ieraugu. Pēdējos gados arī Latvijā arvien plašāk tiek lietots termins ,,pilngraudu maize”. Tā ir maize, kuru gatavo no kviešu vai rudzu pilngraudu miltiem, un tiem maizes sastāvā jābūt ne mazāk par $90 \%$ no kopējā miltu daudzuma. Pilngraudu miltu sastāvā ir visas grauda sastāvdaḷas, tajā skaitā dīglītis, graudapvalki un endosperma. Pilngraudu milti var būt samalti rupjākā vai smalkākā frakcijā. Pārtikas drošības nolūkos piel̦aujama neliela (līdz 2\%) graudu dalı (virsējā grauda apvalka) atdalīšana (Kunkulberga \& Seglinšs, 2010). Latvijā ražotie rupjie rudzu milti atbilst pilngraudu miltu definīcijai, jo ražošanas procesā tiek notīrìts grauda virsslānis, kas veido ne vairāk par $2 \%$ no visa grauda. No šiem miltiem ražotā maize atbilst pilngraudu maizes nosaukumam.

Maizes gatavošanas process sākas ar miltu plaucēšanu: aptuveni trešdaļu rudzu miltu aplej ar karstu ūdeni un rūpīgi izmaisa (1. att.). Šajā procesā miltos esošā ciete sadalās līdz vienkāršajiem cukuriem, plaucējums pamazām atdziest, iecukurojas un kḷūst salds. Lai šis process noritētu ātrāk, plaucējumam pievieno fermentatīivi aktīvu rudzu iesalu. Pēc tam plaucējumu atdzesē un pievieno ieraugu, kurā ir aktīvas pienskābes baktērijas. Šādi plaucējums tiek ieskābēts un ieraudzēts un rodas rudzu maizei raksturīgā saldskābā garša. Kad ieraugs ir pietiekami uzrūdzis un ieskābis, abrā tiek gatavota mīkla: ieraugam pievieno miltus, ūdeni, cukuru, ķimenes un sāli. Mīklas tālākās raudzēšanas laikā galvenokārt veidojas pienskābe, mazāk - etiksskābe un citas organiskās skābes. Procesa laikā izdalās og̣̦skābā gāze, kura irdina mīklu un piešksir maizei porainību. Kopējais rūgšanas process ilgst 36 stundas, kuru noslēdz kukulīša veidošana un cepšana.

\footnotetext{
* Corresponding author's email: vro@apollo.lv
} 


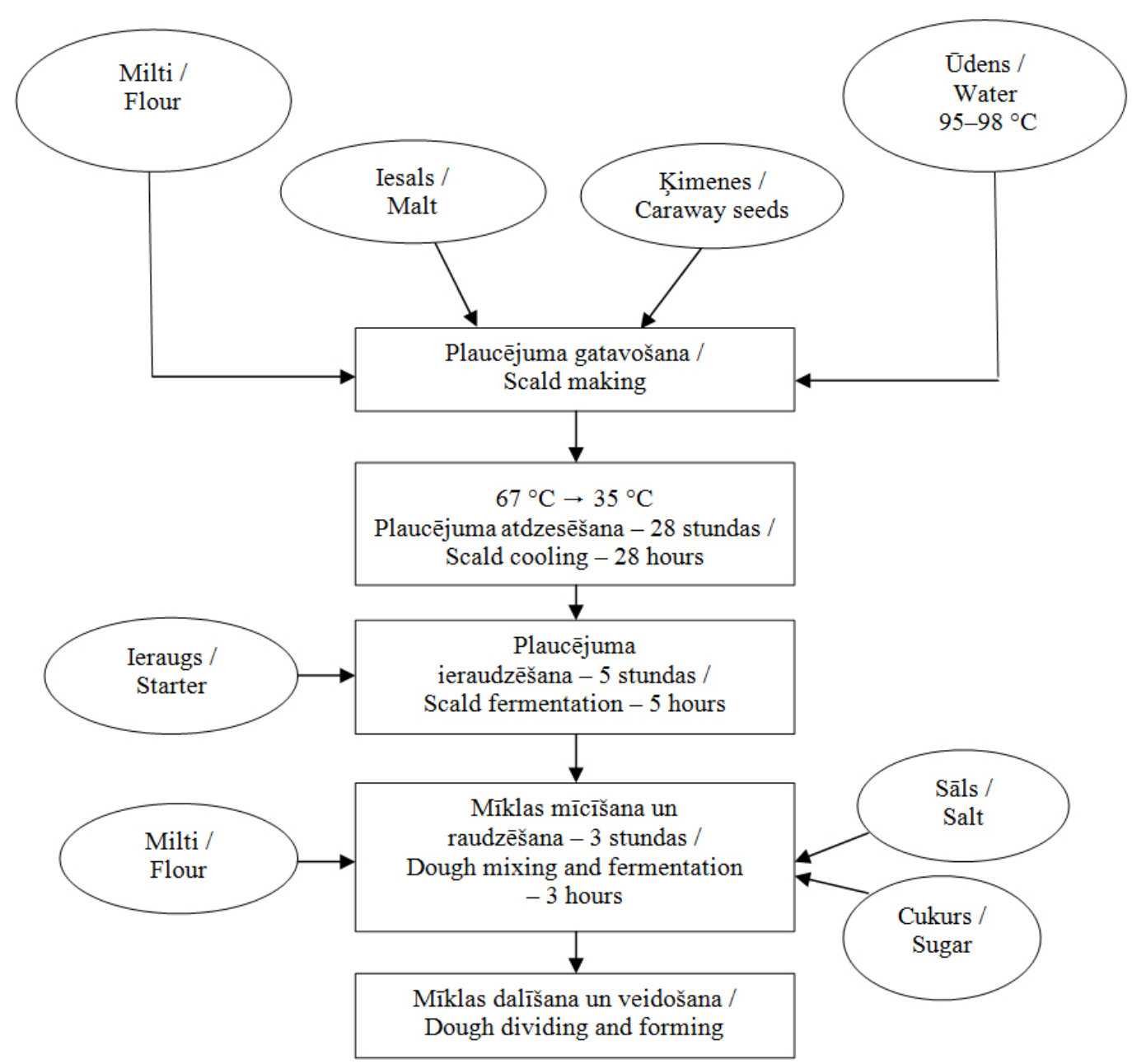

1. att. Rudzu pilngraudu mīklas gatavošanas tehnoloǵija un režīmi.

Fig. 1. The scheme of whole grain rye dough making and conditions.

Svarīgākais posms visā maizes gatavošanas procesā ir cepšana. Cepšanas laikā nestabila un mitra mīkla kḷūst par garšīgu izstrādājumu ar pietiekami sausu, elastīgu mīkstumu un stingru garozu. Tieši cepšanas procesā notiek izstrādājuma kvalitātes veidošanās, tādēl svarīgi zināt, kas notiek šajā laikā un kā šos procesus var ietekmēt, virzìt un panākt nepieciešamo rezultātu.

Cepšanas laikā maizes klaipa virskārtā veidojas brūna garoza un būtiski pastiprinās maizes aromāts. Garoza ir loti jutīgs izvēlētās tehnolog̣ijas un tās ievērošanas rādītājs. Ja cepšanas process ir par ilgu, tas ietekmē kvalitāti - garoza ir par tumšu un cietu, maizes apjoms ir samazināts, un dažreiz pat jūtama rūgta garša; un pretēji - ja cepšanas ilgums bijis par issu, tad maizei ir nepietiekams aromāts, neizteikta garša un neapmierinošas mīkstuma īpašības (Kunkulberga \& Segliņš, 2010).

Latvija ir bagāta ar senu pilngraudu rudzu maizes gatavošanas vēsturi, bet trūkst informācijas par tās vērtību patērētāju veselības nodrošināšanai. Pēdējo gadu zinātniskie pētījumi (Lindhauer, 2008; Martinez-Villaluenga et al., 2009; Nystrom et al., 2008) pārtikas tehnologijiā un medicīnā paver iespējas noteikt un izvērtēt tādu pārtikas sastāvdalı ietekmi uz patērētāju veselību, kuras mērāmas vissīkākajās svara vienībās - miligramos un mikrogramos.

Vitamīni ir biologiski aktīvi savienojumi, kas nelielos daudzumos atrodami graudaugos, tomēr zinātnieki visā pasaulē veic pētījumus, vērtējot vitamīnu pozitīvo ietekmi uz patērētāja veselību (Montonen, Knekt, Jarvinen, Aromaa, \& Reunanen, 2003; Parikka, Rowland, Welch, \& Wahala, 2006; Ward et al., 2008).

Viens no biolog̣iski aktīvo savienojumu avotiem ir rudzi, kas pēdējos gados nepelnīti zaudē popularitāti Latvijas ražotāju un patērētāju vidū. Izvērtējot citu valstu pieredzi, ievērības cien̄̄gs ir Somijas piemērs. Laika posmā no 1960. gada līdz 2000. gadam rudzu produktu patērinšs gadā 
uz vienu iedzīvotāju Somijā samazinājās no 30 līdz $15 \mathrm{~kg}$. Zinātniekiem veicot pētījumus un informējot sabiedrību par rudzu produktu pozitīvo ietekmi uz patēēêāju veselību, rudzu popularitāte tika atgūta. No 2004. gada rudzu produktu patēriņš Somijā sāka palielināties, kā rezultātā samazinājās sirds un asinsvadu slimību izraisīto nāves gadījumu skaits (Lehtinen, Kaukovirta-Norja, \& Poutanen, 2009). Salīdzinoši Latvijā rudzu maizes patēriņš pēdējā desmitgadē ir samazinājies no 33 līdz 19 kg uz vienu iedzīvotāju gadā. Latvijā mirstība sirds un asinsvadu slimību dẹl ieņem pirmo vietu pārējo nāves cēloṇu vidū - ik gadu mirst 16 līdz 18 tūkst. iedzīvotāju (LR CSP, 2010). Šo rādīiāju, iespējams, varētu samazināt, ja uzturā vairāk tiktu lietoti rudzu produkti, kas satur vitamīnus un šķiedrvielas.

Daudzu valstu zinātnieki pierādījuši, ka rudzu maizes regulāra lietošana uzturā atstāj pozitīvu ietekmi uz patērētāju veselību - samazinās sirds un asinsvadu saslimšanas risks, tiek kavēta krūts un zarnu trakta audzēju veidošanās, uzlabojas gremošana, tiek kavēta holesterīna absorbcija un samazinās 2. tipa cukura diabēta risks (Seal, 2006; Schatzkin et al., 2000; Montonen et al., 2005).

Rudzu maize bez og̣̣hidrātiem un olbaltumvielām satur biolog̣iski aktīvus savienojumus - šķiedrvielas, minerālvielas, vitamīnus un antioksidantus, kas labvēlīgi ietekmē patērētāju veselību, palielina spēju pretoties dažādām slimībām un paaugstina imunitāti (Montonen, Knekt, Jarvinen, Aromaa, \& Reunanen, 2003; Liu et al., 2000; Hiller, Schlormann, Glei, \& Lindhauer, 2011).

Rudzu maizes galvenā priekšrocība salīdzinājumā ar kviešu maizi ir tās augstais šķiedrvielu un vitamīnu saturs (Poutanen, 1997).

Latvijas Pārtikas tehnolog̣iju platformas (LPTP) Darbības un attīstības stratēgijā 2008.-2020. gadam viens no mērķiem ir kvalitatīvas, veselīgas un drošas pārtikas ražošanas veicināšana, par primāro uzskatot patērētāju intereses. Pamatojoties uz izvirzītajiem mērķiem, jāveic padzị̣nāti pētījumi par Latvijā ceptas pilngraudu rudzu maizes ķīmisko sastāvu.

Šî pētījuma mērķis bija noteikt vitamīnu saturu un tā izmaiņas pilngraudu rudzu maizes cepšanas procesā - miltos, mīklā un maizē.

\section{Materiāli un metodes}

Pētījums veikts 2011. gada ruden̄i Latvijas Universitātes Biologijas institūtā un Pārtikas un biotehnolog̣ijas kompetences centrā Tallinā, Igaunijā.
Pētījumā analizēja rudzu pilngraudu miltus, uzraudzētu rudzu miltu mīklu un rudzu maizi, kas cepta 30, 45, 60 un 75 minūtes. Pētîjumos par maizi atsevišķi analizēja maizes garozu un mīkstumu. Vidējos paraugus sagatavoja atbilstoši katrai analīžu metodei un pēc nepieciešamības saldēja un sublimēja. Miltu kvalitātes rādītāju un vitamīnu noteikšanai, kā arī maizes cepšanai izmantoja AS ,Jelgavas dzirnavas" ražotos rudzu pilngraudu miltus ar pelnvielu saturu $-1.72 \%$, mitrumu $-12.3 \%$, proteīna saturu $-8.8 \%$, un krišanas skaitli $-160 \mathrm{~s}$.

Mīklas gatavošanai izmantoja rudzu pilngraudu miltus, cukuru, sāli, nefermentēto rudzu iesalu, ķimenes un ūdeni. Mīklu gatavoja pēc tradicionālas rudzu maizes gatavošanas tehnologijas, kas sastāv no plaucējuma gatavošanas, atdzesēšanas un ieraudzēšanas, mīklas mīcǐšanas, mīklas raudzēšanas, mīklas dalīšanas, klaipu veidošanas un cepšanas (1. att.). Plaucējumu gatavo, ķimenes un vienu trešdalıu no kopējā miltu daudzuma aplejot ar karstu ūdeni. Kad plaucējuma temperatūra ir $67 \pm 2{ }^{\circ} \mathrm{C}$, pievieno rudzu nefermentēto iesalu un labi izmaisa. Plaucējumu divas stundas atstāj koka kublā, kur tas gatavots, lai notiktu cietes pārcukurošanās process. Pēc tam plaucējumu ik pa četrām stundām maisa. Plaucējuma atdzesēšana norit 28 stundas. Kad plaucējuma temperatūra ir $35 \pm 1{ }^{\circ} \mathrm{C}$, tajā ieliek ieraugu, lai sāktos intensīva pienskābā rūgšana. Kopējais plaucējuma ieraudzēšanas laiks ir piecas stundas. Kad plaucējums uzrūdzis, mīca mīklu. Uzraudzētam plaucējumam pievieno pārējos miltus, cukuru un sāli. Mīklu mīca 15-20 minūtes, kamēr visas sastāvdaļas ir vienmērīgi izmaisītas. Mīklu trīs stundas raudzē, tad to dala $1 \mathrm{~kg}$ gabalos, veido klaipus un cep. Vispirms klaipus vienu minūti apcep $400{ }^{\circ} \mathrm{C}$ temperatūrā apcepšanas krāsnī, pēc tam tos tālākai cepšanai pārcel krāsnī uz klona $250{ }^{\circ} \mathrm{C}$ temperatūrā.

Cepšanas laikā temperatūru mērijāam uz klaipa virsmas un klaipa iekšienē, izmantojot termopārus. Paraugu cepšanas ilgums un temperatūras izmaiñas dotas 1. tabulā. Izveidotā maizes klaipa optimālais cepšanas ilgums ir 60 minūtes. Pēc apcepšanas mīklas sagataves centrā temperatūra bija $37 \pm 0.1{ }^{\circ} \mathrm{C}$, temperatūra garozā $-74 \pm 7.5^{\circ} \mathrm{C}$. Pēc cepšanas maizes klaipus 12 stundas atdzesēja telpas temperatūrā. Pēc atdzesēšanas tos sagrieza škēelēs un, atdalot mīkstumu no garozas, ieguva paraugus analī̌̌u veikšanai. Garozas biezums atkarībā no maizes cepšanas laika bija 2-7 mm.

Vitamīnu saturu pilngraudu rudzu miltos un mīklā, kā arī maizes mīkstumā un garozā cepšanas laikā analizēja pēc 30, 45, 60 un 75 min. saskaņā ar 
Maizes paraugu raksturojums

1. tabula / Table 1

Characteristics of bread samples

\begin{tabular}{cccc}
\hline $\begin{array}{c}\text { Rudzu maizes } \\
\text { klaipa Nr. } \\
\begin{array}{c}\text { No. of the rye } \\
\text { bread loaf }\end{array}\end{array}$ & $\begin{array}{c}\text { Cepšanas laiks / } \\
\text { Baking time, min }\end{array}$ & $\begin{array}{c}\text { Temperatūra } \\
\text { maizes mīkstuma centrā / } \\
\text { Temperature of crumb, } \\
{ }^{\circ} \mathrm{C}\end{array}$ & $\begin{array}{c}\text { Temperatūra maizes garozā / } \\
\text { Temperature of crust, } \\
{ }^{\circ} \mathrm{C}\end{array}$ \\
\hline 1 & 30 & $91 \pm 3.0$ & $140 \pm 5.5$ \\
\hline 2 & 45 & $99 \pm 0.4$ & $146 \pm 5.5$ \\
\hline 3 & 60 & $100 \pm 0.2$ & $152 \pm 3.5$ \\
\hline 4 & 75 & $100 \pm 0.3$ & $171 \pm 1.5$ \\
\hline
\end{tabular}

Piezīme. Cepšanas temperatūra krāsnī $-250 \pm 2{ }^{\circ} \mathrm{C}$.

Note. Baking temperature in the oven $-250 \pm 2{ }^{\circ} \mathrm{C}$.

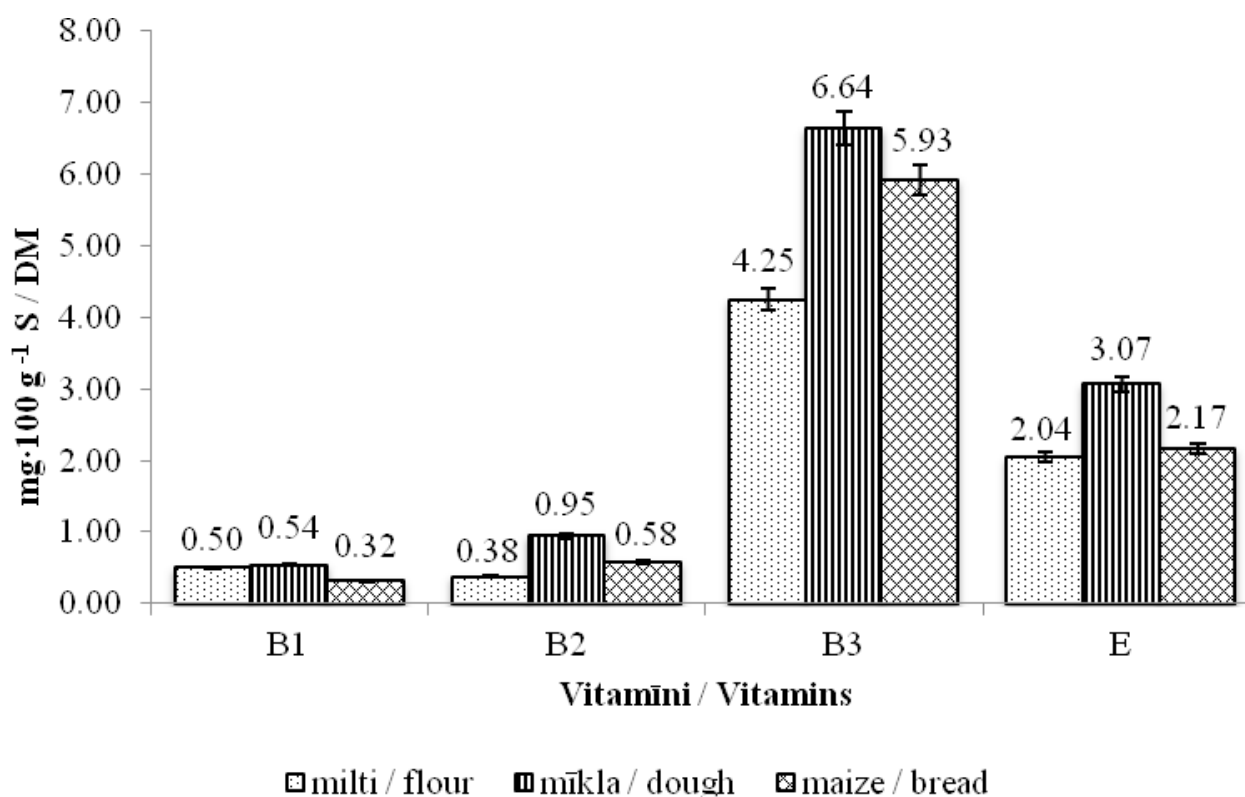

2. att. Vitamīnu saturs pilngraudu rudzu miltu, mīklas un maizes sausnā.

Fig. 2. Vitamin content in DM of whole grain rye flour, dough and bread.

Kanādas Analītiskās ķīmijas asociācijas (AOAC) apstiprinātajām standarta metodēm:

- tiamīnu $\left(\mathrm{B}_{1}\right)$ - AOAC 986.27;

- riboflavīnu $\left(\mathrm{B}_{2}\right)$ - AOAC 970.65;

- $\operatorname{niacīnu}\left(\mathrm{B}_{3}\right)$ - AOAC 942.23;

- $\quad \alpha$-tokoferolu (E ) - AOAC 971.30.

Visas iepriekšminētās analīzes tika veiktas Latvijas Universitātes Bioloǵijas institūtā.

Pilngraudu rudzu miltos un maizē noteica B grupas kompleksa vitamērus (tiamīnu, riboflavīnu, niacīnu, nikotīnamīdu, pantotēnskābi, piridoksālu, piridoksīnu) ar šksidruma hromatogrāfamasas spektrometra tandēmu, izmantojot stabilo izotopu atšksaidīšanas metodi (Mihhalevski,
Nisamedtinov, Halvin, Ošeka, \& Paalme, 2013). Šīs analīzes tika veiktas Tallinas Pārtikas un biotehnologijas kompetences centrā, Igaunijā.

Datu statistiskā apstrāde veikta, izmantojot statistisko datu apstrādes SPSS un Microsoft Excel programmas. Būtiskums pārbaudīts ar $p$ vērtības metodi, un faktori novērtēti par būtiskiem, ja $p$ vērtība bija $<\alpha_{0.05}$. Pieñemts, ka $\alpha=0.05$ ar $95 \%$ ticamību (Arhipova \& Bāliņa, 2003).

\section{Rezultāti un diskusija}

Vitamīni ir vitāli nepieciešami normālai dzīvības procesu norisei organismā, tie nodrošina organisma augšanu, attīstību un imunitātes stiprināšanu. Ražojot 
rudzu maizi, ir svarīgi, lai tajā saglabātos maksimāls vitamīnu daudzums, kas atrodas rudzu graudos. Lai to nodrošinātu, maizes cepšanai jāizmanto rudzu pilngraudu jeb rudzu rupjos miltus, kas satur endospermu, dīglīti un visas grauda apvalka dal̦as un ir galvenais vitamīnu un šķiedrvielu avots. Pētījuma uzdevums bija izvērtēt, kā mainās vitamīnu saturs maizes ražošanas procesā un cik lieli ir to zudumi cepšanas laikā.

Vitamīnu satura izvērtēšanai tika noteikts tiamīna ( $B_{1}$ vitamīns), riboflavīna ( $B_{2}$ vitamīns), niacīna (sinonīmi - PP vai $\mathrm{B}_{3}$ vitamīns, nikotīnskābe, nikotīnamīds, niacīnamīds) un $\alpha$-tokoferola (E vitamīns) saturs miltos un mīklā, kā arī rudzu maizē ar atšksirīgu cepšanas laiku. Vitamīnu saturs miltos, mīklā un maizē parādīts 2. attēlā. Tiamīna saturs miltos un mīklā attiecīgi bija 0.5 un $0.54 \mathrm{mg}$ $100 \mathrm{~g}^{-1}$ sausnas un būtiski neatškīīās $(p=0.135)$. Tas nozīmē, ka raudzēšanas laikā tiamīna saturs būtiski nepalielinājās. Savukārt zinātniskajā literatūrā aprakstîti pētījumi, kuros konstatēts, ka, mīklu raudzējot ar raugu un pagarinot raudzēšanas laiku, var panākt tiamīna satura palielināšanos, bet, izmantojot ieraugu un pienskābes baktērijas, iespējama tiamīna daudzuma samazināšanās (Khetarpaul \& Chauhan, 1989).

Mūsu pêtījumā tiamīna saturs rudzu maizē (0.32 mg $100 \mathrm{~g}^{-1}$ sausnas) bija mazāks nekā mīklā un miltos. Rezultāti rāda, ka tiamīna zudums maizes cepšanas laikā bija 36\%. Par līdzīgu pētījumu rezultātiem ziņojuši vairāki pētnieki - piemēram, Hagg and Kumpulainen (2002) un MartinezVillaluenga et al. (2009) noskaidrojuši, ka tiamīna zudums termiskajos procesos veido līdz $53-65 \%$ no tā satura miltos.

Mūsu pētījuma rezultāti par riboflavīna satura izmaiņām liecināja, ka mīklā tas ir divas reizes lielākā daudzumā nekā miltos un rūgšanas laikā palielinās no 0.38 līdz $0.95 \mathrm{mg} 100 \mathrm{~g}^{-1}$ sausnas, turklāt šī atšķirība ir būtiska $(p=0.001)$. Savukārt rudzu maizē

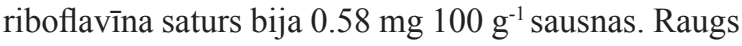
un pienskābes baktērijas rūgšanas procesā sintezē ūdenī šķ̄istošos vitamīnus, tādēl to saturs mīklā, salīdzinot ar miltos esošo, palielinās. Mūsu iegūtie rezultāti apstiprina zinātniskajā literatūrā pausto atziņu, ka maizes raudzēšanas laikā riboflavīna saturs palielinās (Batifoulier, Verny, Chanliaud, Remesy, \& Demigne, 2005).

Niacīna saturs mīklas raudzēěanas laikā palielinājās - miltos un mīklā tas bija attiecīgi 4.25 un $6.64 \mathrm{mg} 100 \mathrm{~g}^{-1}$ sausnas. Maizes cepšanas laikā niacīna saturs samazinājās par $11 \%$, tomēr maizē tas bija lielākā daudzumā nekā sākotnēji miltos.

Analizējot $\alpha$-tokoferola satura izmainas mīklas raudzēšanas un maizes cepšanas laikā, vērojām tendenci, kas bija līdzịga niacīna satura izmain̄ām. Mīklas raudzēšanas laikā $\alpha$-tokoferola saturs nedaudz palielinājās - no $2.04 \quad$ līdz $3.07 \mathrm{mg} 100 \mathrm{~g}^{-1}$ sausnas. Tas atbilst citu pētijumu atziņām, ka miltu plaucēšana un mīklas raudzēšana neatstāj būtisku ietekmi uz $\alpha$-tokoferola saturu maizē (Hakansson \& Jagerstad, 1990; Wennermark \& Jagerstad, 1992; Liukonen et al., 2003). Mūsu pêtījumā maizes cepšanas laikā $\alpha$-tokoferola saturs samazinājās par $30 \%$ salīdzinājumā ar tā saturu mīklā.

Maize sastāv no divām dạ̦ām - maizes mīkstuma un garozas. To fizikālās īpašības un ķīmiskais sastāvs ir atšksirīgs. Lai izvērtētu, kā mainās vitamīnu sastāvs mīkstumā un garozā, tika analizēts vitamīnu saturs katrā maizes dal̦ā atsevišksi. Šobrīd tas ir īpaši aktuāli, jo pēdējos gados daudz tiek diskutēts par garozas drošību un veselīgumu.

Vitamīnu saturs un tā izmaiņas mīklā (cepšanas laiks -0 min) un maizes mīkstumā un garozā dažādos cepšanas posmos parādīts 3. un 4. attēlā. Redzams, ka maizes mīkstumā un garozā tiamīna, riboflavīna un $\alpha$-tokoferola daudzums jau pēc pirmajām 30 cepšanas minūtēm samazinās par 30$50 \%$, salīdzinot ar to saturu mīklā. Turpinot cepšanu, vitamīnu saturs maizē vairs būtiski nemainījās, taču, pārsniedzot optimālo cepšanas ilgumu (60 minūtes) par 15 minūtēm, konstatējām, ka vitamīnu daudzums samazinājies vēl par $8 \%$ ( $\alpha$-tokoferols) un par 22\% (tiamīns). Piecpadsmit minūšu novirze no optimālā cepšanas laika izvēlēta, lai varētu novērtêt izmaiņas arī pārceptā maizē.

Tiamīna saturs cepšanas laikā mīkstumā un garozā samazinājās par 45-48\% salīdzinājumā ar tā saturu mīklā, bet, pārsniedzot optimālo cepšanas laiku par 15 minūtēm, tā daudzums samazinājās par 47-59\%. Tiamīna satura izmaiņas būtiski ietekmēja cepšanas laiks, īpaši cepšanas posmi no 30 . līdz 45. minūtei un no 60. līdz 75. minūtei $(p=0.001)$.

Riboflavīna un tiamīna satura izmaiņas maizes cepšanas laikā bija līdzīgas - riboflavīna saturs mīkstumā un garozā būtiski atšķīrās $(p=0.001)$, ar vidējo starpību $0.11 \pm 0.02 \mathrm{mg} 100 \mathrm{~g}^{-1}$ sausnas. Salīdzinājumā ar riboflavīna saturu mīklā, tā daudzums cepšanas laika posmā no 60 . līdz 75. minūtei $(p=0.001)$ būtiski samazinājās: par $47 \%$ mīkstumā un par 57\% garozā. Riboflavīna satura izmaiņas temperatūras ietekmē raksturo vidēji 


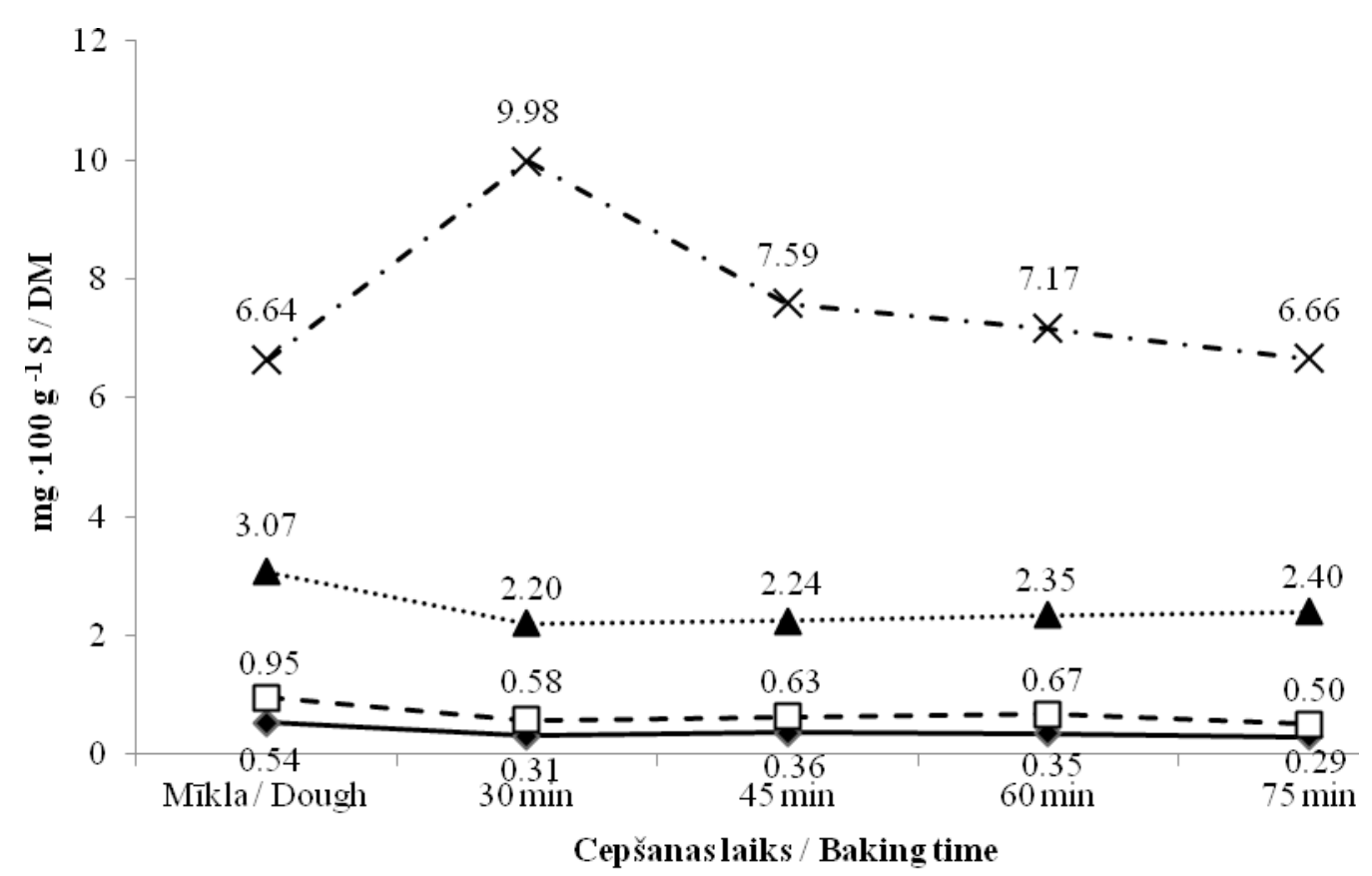

$\longrightarrow-\mathrm{B} 1 \quad-\sqcap-\mathrm{B} 2 \cdots \cdots \cdot \mathrm{F}-\times-\mathrm{B} 3$

3. att. Vitamīnu saturs pilngraudu rudzu maizes mīklā un mīkstumā cepšanas laikā.

Fig. 3. Vitamin content in whole grain rye bread dough and crumb during baking.

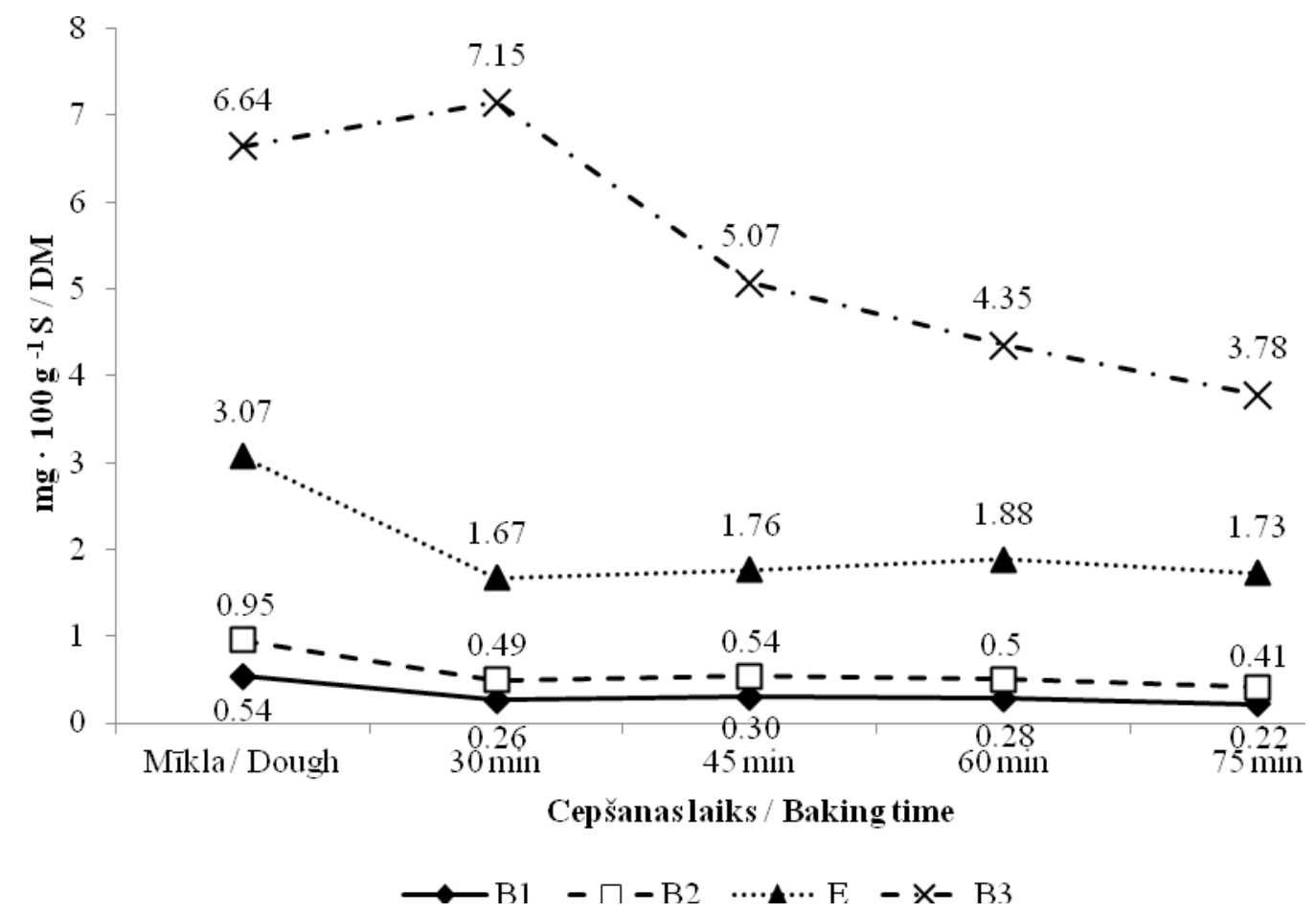

4. att. Vitamīnu saturs pilngraudu rudzu maizes mīklā un garozā cepšanas laikā.

Fig. 4. Vitamin content in whole grain rye dough and crust during baking.

cieša korelācija $(r=0.595)$, kur $35 \%$ no riboflavīna daudzuma izmaiņām var izskaidrot ar temperatūras ietekmi. $\alpha$-tokoferola saturs mīkstumā un garozā būtiski atšksīās $(p=0.001)$ - garozā tas bija mazāks nekā mīkstumā, un vidējā starpība bija $0.537 \pm 0.055 \mathrm{mg}$ 
Ražošanas faktoru ietekme uz vitamīnu saturu pilngraudu rudzu maizē Influence of processing factors on vitamin content in whole grain rye bread

\begin{tabular}{|c|c|c|c|c|c|}
\hline \multicolumn{2}{|c|}{$\begin{array}{l}\text { Faktors / } \\
\text { Factor }\end{array}$} & $\begin{array}{l}\text { Tiamīns / } \\
\text { Thiamine }\end{array}$ & $\begin{array}{l}\text { Riboflavīns / } \\
\text { Riboflavine }\end{array}$ & $\begin{array}{l}\text { Niacin / } \\
\text { Niacin }\end{array}$ & $\begin{array}{r}\alpha \text {-tokoferols / } \\
\alpha \text {-tocopherol }\end{array}$ \\
\hline \multicolumn{2}{|c|}{$\begin{array}{l}\text { Faktors (mīkstums vai garoza) / } \\
\text { Factor (crumb or crust) }\end{array}$} & $0.001^{*}$ & $0.001 *$ & $0.001 *$ & $0.001 *$ \\
\hline \multicolumn{2}{|c|}{ Temperatūra / Temperature } & 0.124 & $0.04 *$ & $0.001 *$ & 0.247 \\
\hline \multicolumn{2}{|c|}{$\begin{array}{l}\text { Cepšanas laiks / } \\
\text { Baking time }\end{array}$} & $0.001 *$ & $0.001^{*}$ & $0.001 *$ & 0.114 \\
\hline \multirow{3}{*}{$\begin{array}{l}\text { Cepšanas etaps/ } \\
\text { Baking stage }\end{array}$} & $30-45 \mathrm{~min}$ & $0.001 *$ & 0.063 & $0.001 *$ & 0.842 \\
\hline & $45-60 \mathrm{~min}$ & 0.414 & 1 & 0.083 & 0.501 \\
\hline & $60-75 \min$ & $0.001<0.05 *$ & $0.001<0.05 *$ & 0.114 & 0.925 \\
\hline
\end{tabular}

* - Faktora ietekme ir būtiska. / Influence of factor is significant.

$100 \mathrm{~g}^{-1}$ sausnas. Maizes cepšanas laikā $\alpha$-tokoferola daudzums mīkstumā samazinājās par $24 \%$, garozā - par 39\%, bet, cepot maizi 75 minūtes, garozā tas samazinājās par 44\%. Cepšanas laikam nebija būtiskas ietekmes uz $\alpha$-tokoferola saturu $(p=0.114)$ nevienā no pētītajiem cepšanas laika posmiem.

Pētījuma rezultāti rāda, ka niacīna satura dinamika cepšanas laikā atšķiras no citu analizēto vitamīnu satura izmain̄ām. Tiamīna, riboflavīna un $\alpha$-tokoferola daudzums cepšanas sākumā samazinājās, bet niacīna saturs par $50 \%$ palielinājās, un tikai cepšanas posmā no 30. līdz 45. minūtei varēja vērot niacīna daudzuma samazināšanos: maizes mīkstumā par $25 \%$, bet garozā par 39\% ( $p=0.001)$. Datu apstrāde liecināja, ka 86.12\% no niacīna satura izmainām var izskaidrot ar temperatūras ietekmi, kas bija būtiska ( $p=0.001)$. Savukārt, pārsniedzot cepšanas ilgumu par 15 minūtēm, niacīna daudzums mīkstumā samazinājās par 33\% un garozā par $62 \%$. Niacīna satura pieaugums cepšanas procesa sākumā skaidrojams ar nikotīnamīda adenīna dinukleotīda (NAD) un tā fosforilētās formas (NADP) sadalīšanos temperatūras ietekmēe, kā rezultātā atbrīvojas nikotīnamīds, kas kā niacīna vitamērs palielina kopējo $B_{3}$ vitamīna saturu maizē (Ball, 2006).

Vitamīnu saturu maizē ietekmē rudzu maizes ražošanas process. Vitamīnu saturu ietekmējošie faktori apkopoti 2. tabulā, kur redzams, ka vitamīnu daudzums maizes mīkstumā un garozā atšķiras $(p=0.001)$. Temperatūra cepšanas procesā būtiski ietekmē riboflavīna un niacīna daudzumu maizē. Cepšanas ilgums ir nozīmīgs faktors B grupas vitamīnu - tiamīna un niacīna - saturam maizē cepšanas sākuma posmā. Optimālā cepšanas laika pārsniegšana ir būtisks faktors vitamīnu zudumiem pilngraudu rudzu maizes cepšanas procesā.

Izmantojot šķidruma hromatogrāfa-masas spektrometra tandēmu, analizējām B vitamīnu kompleksa vitamērus rudzu pilngraudu miltos un rudzu maizē. Vitamēri ir vitamīnu formas, kas atšķkiras ar ķīmisko struktūru, bet ir ar vienādu bioloǵisko aktivitāti. Niacīnam $\left(\mathrm{B}_{3}\right)$ ir divi vitamēri nikotīnskābe un nikotīnamīds -, savukārt $\mathrm{B}_{6}$ vitamēri ir piridoksīns un piridoksāls (Ball, 2006a).

Mūsu pētījumā iegūtie rezultāti (5. att.) ir izmantojami relatīvam pārtikas produktu novērtējumam, jo ar šīs analīzes palīdzību nevar noteikt tos B vitamīnu kompleksus, kuri produkta matricā atrodas fosforilētā vai glikozilētā formā.

Konstatējām, ka miltu sausnā $\mathrm{B}_{3}$ nikotīnamīda formā bija $56 \mu \mathrm{g}$ un niacīna formā - $203 \mu \mathrm{g}$ $100 \mathrm{~g}^{-1}$ sausnas. Rudzu maizē B nikotīnamīda formā bija $607 \mu \mathrm{g} 100 \mathrm{~g}^{-1}$ sausnas, turklāt maizes cepšanas procesā tā daudzums palielinājās vairāk nekā 10 reizes. Savukārt $\mathrm{B}_{3}$ niacīna formā maizē bija $126 \mu \mathrm{g} 100 \mathrm{~g}^{-1}$ sausnas, kas ir par 38 \% mazāk nekā miltos.

Pantotēnskābes saturs miltos un maizē bija vienāds, kas apstiprina tās termisko stabilitāti, ja pH ir no 5 līdz 7. Tā kā pantotēnskābe ietilpst acilēšanas kofermenta sastāvā, kam ir nozīmīga loma vielmaiņas procesos, var teikt, ka tā palielina rudzu maizes bioloǵisko vērtību.

Pētījumā noskaidrojām, ka rudzu pilngraudu maize satur arī piridoksālu un piridoksīnu, kas ir $\mathrm{B}_{6}$ vitamīna vitamēri un kas graudu produktos atrodas 


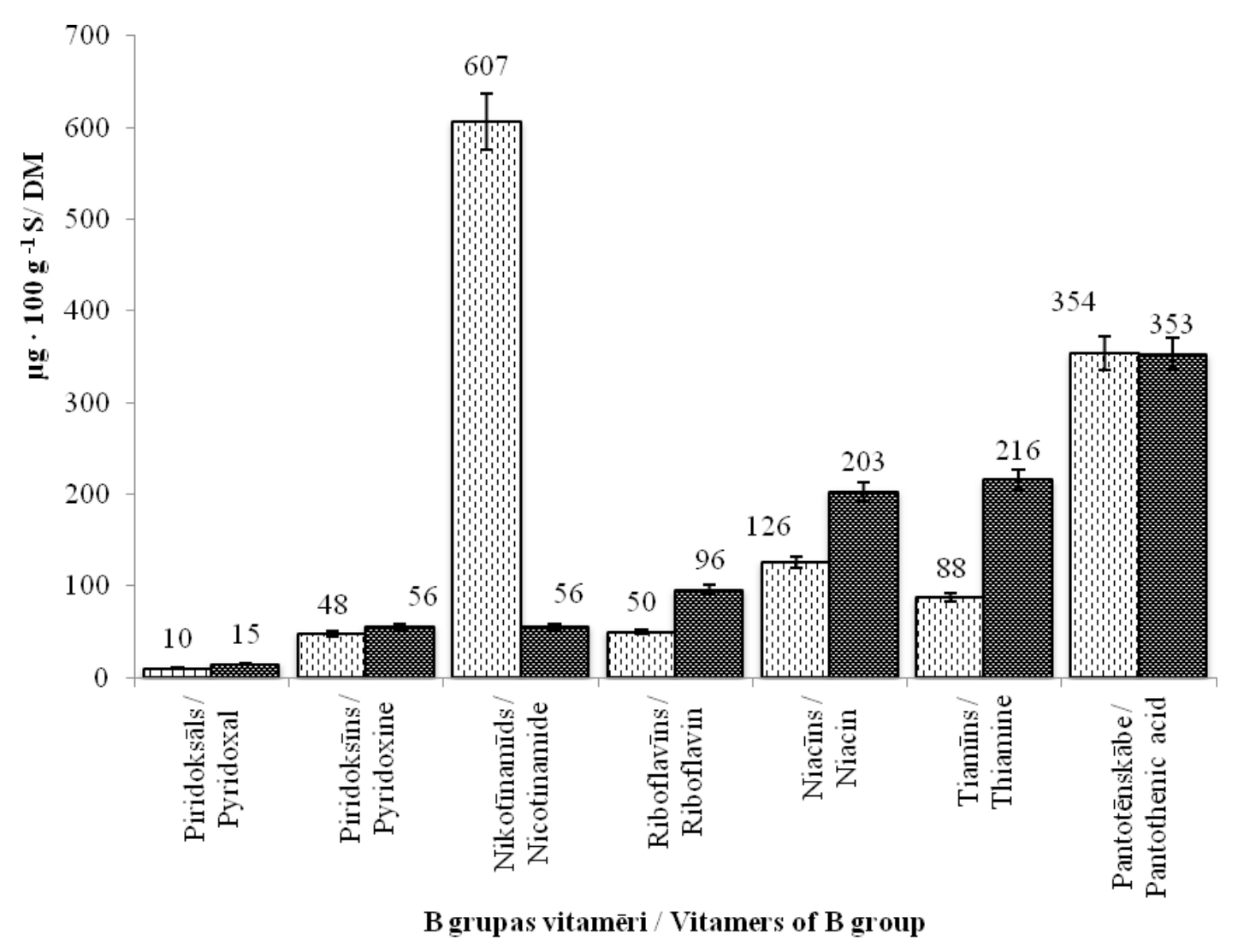

Dmaize / bread 圈milti / flour

5. att. B vitamēru komplekss pilngraudu rudzu miltos un maizē.

Fig. 5. Complex of B vitamers in whole grain rye flour and bread.

3. tabula / Table 3

Vitamīnu saturs $100 \mathrm{~g}$ maizes un to ieteicamās dienas devas (IDD) Vitamin content in $\mathbf{1 0 0} \mathrm{g}$ of bread and recomended daily allowances (RDA)

\begin{tabular}{|c|c|c|c|c|}
\hline Maize / Bread & $\begin{array}{l}\text { Tiamīns / } \\
\text { Thiamine, } \\
\text { mg }\end{array}$ & $\begin{array}{l}\text { Riboflavīns / } \\
\text { Riboflavine, } \\
\text { mg }\end{array}$ & $\begin{array}{l}\text { Niacīns / } \\
\text { Niacin, } \\
\text { mg }\end{array}$ & $\begin{array}{l}\alpha \text {-tokoferols / } \\
\alpha \text {-tocopherol, } \\
\text { mg }\end{array}$ \\
\hline $\begin{array}{l}\text { Eksperimenta maize / } \\
\text { Experimental bread }\end{array}$ & $0.23 \pm 0.015$ & $0.41 \pm 0.006$ & $4.24 \pm 0.100$ & $1.55 \pm 0.012$ \\
\hline $\begin{array}{l}\text { Sausmaizìte / } \\
\text { Crispbread (EuroFir, 2011) }\end{array}$ & 0.24 & 0.27 & 4 & 1.36 \\
\hline $\begin{array}{l}\text { „Kaimiška” } \\
\text { (EuroFir, 2011) }\end{array}$ & 0.17 & 0.13 & 1.6 & 1.69 \\
\hline $\begin{array}{l}\text { Maize ar aktivētiem graudiem / } \\
\text { Bread with activated grain (Rakčejeva, } \\
\text { 2006) }\end{array}$ & 0.32 & 0.11 & 1.38 & 1.88 \\
\hline $\begin{array}{l}\text { Pilngraudu rudzu maize / } \\
\text { Whole grain rye bread (Fineli, 2010) }\end{array}$ & 0.20 & 0.15 & 2.7 & 0.8 \\
\hline $\begin{array}{l}\text { IDD, mg pieaugušajiem / } \\
\text { RDA, mg for adults } \\
\text { (LR Veselības ..., 2008) }\end{array}$ & 1.2 & 1.6 & 16 & 12 \\
\hline $\begin{array}{l}\text { Eksperimentālā maize, \% no IDD / } \\
\text { Experimental bread, \% of RDA }\end{array}$ & $19 \%$ & $26 \%$ & $27 \%$ & $13 \%$ \\
\hline
\end{tabular}


glikozilētā formā, tāpēc to saturu miltos un maizē nevar izvērtêt, taču to klātbūtne maizē ir l̦oti svarīga. Pētījums parādīja, ka rudzu maize satur plašu spektru B kompleksa vitamīnus $-\mathrm{B}_{1}, \mathrm{~B}_{2}, \mathrm{~B}_{3}, \mathrm{~B}_{5}$ un $\mathrm{B}_{6}$.

Salīdzinot mūsu pētījumā iegūtos datus ar literatūras datiem par vitamīnu saturu līdzīgos maizes paraugos un saskaņā ar Veselības ministrijas 2008. gada 15. oktobra rīkojumu Nr. 174 „Ieteicamās energíjas un uzturvielu devas Latvijas iedzīvotājiem" (LR Veselības ministrija, 2008), redzams, ka lielākais ieteicamās dienas devas (IDD) segums, ēdot rudzu pilngraudu maizi, ir riboflavīna, niacīna un tiamīna saturam. Apēdot $100 \mathrm{~g}$ Lietuvā ražoto rudzu maizi „Kaimiška”, patērētājs uzņem 14\% tiamīna, $8 \%$ riboflavīna, $10 \%$ niacīna un $14 \% \alpha$-tokoferola no IDD. Salīdzinot Lietuvā un Latvijā ceptās maizes sastāvu, konstatējām, ka maize „Kaimiška” satur mazāk B grupas vitamīnu, bet ir bagātāka ar $\alpha$-tokoferolu.

Saskaṇā ar Eiropas Padomes direktīvu 90/496/EEC (Council Directive ..., 1990) maize satur ievērojamu vitamīnu daudzumu, ja to saturs ir vismaz $15 \%$ no IDD $100 \mathrm{~g}$ produkta. Rudzu pilngraudu maize ir būtisks vitamīnu avots iedzīvotāju uzturā, jo $100 \mathrm{~g}$ pilngraudu rudzu maizes no IDD satur $19 \%$ tiamīna, $26 \%$ riboflavīna, $27 \%$ niacīna un $13 \% \alpha$-tokoferola.

Vitamīnu satura salīdzinājums starp pētījuma objektu - ražošanas uzņēmumā ceptu rudzu maizi - un literatūrā atrastajiem datiem un IDD dots 3. tabulā. Mūsu pētījumā iegūtie rezultāti apstiprina pilngraudu rudzu maizes nozīmību patērētāju ikdienas uzturā. Izvēloties pilngraudu rudzu maizi, patēēêtāji veicina veselības saglabāšanu.

Ražotāji var iegūt vitamīniem bagātāku maizi, ja izvēlēsies pilngraudu miltus, garāku mīklas raudzēšanas laiku un optimālu cepšanas laiku rudzu maizes ražošanas procesā.

\section{Secinājumi}

1. Vitamīnu saturu rudzu maizes cepšanas procesā ietekmē cepšanas ilgums, temperatūra un izvietojums klaipā (mīkstums vai garoza).

2. Maizes cepšanas procesā vitamīnu saturs garozā samazinās vairāk nekā mīkstumā, ar būtisku vitamīnu koncentrācijas atšķirību $(p=0.001)$.

3. Salīdzinot ar vitamīnu saturu miltos, cepšanas procesā maizē tiamīna saturs samazinājās par $36 \%$, bet riboflavinna, niacīna un $\alpha$-tokoferola daudzums palielinājās attiecīgi par $53 \%, 40 \%$ un $6 \%$.

4. Pētijuma objekts - rudzu pilngraudu maize - ir ievērojams tiamīna, riboflavīna un niacīna avots patērētāju uzturā, kā arī satur plašu spektru citu B grupas vitamēru: nikotīnamīdu, pantotēnskābi, piridoksālu un piridoksīnu.

\section{Literatūra}

1. Arhipova, I., \& Bāliņa, S. (2003). Statistika ekonomikā. Risinājumi ar SSPS un Microsoft Excel. Mācību līdzeklis. Rīga: Datorzinību centrs.

2. Ball, G. (2006). Vitamins in foods. Analysis, bioavailability, and stability. London, New York: CRC Press, Taylor \& Francis group.

3. Batifoulier, F., Verny, M.A., Chanliaud, E., Remesy, C., \& Demigne, C. (2005). Effect of different breadmaking methods on thiamine, riboflavin and pyridoxine contents of wheat bread. Journal of Cereal Science, 42, 101-108.

4. Council Directive of 24 September 1990 on nutrition labelling for foodstuffs (90/496/ EEC). (1990). Official Journal of the European Communities, L. 276, 40-44.

5. EuroFir. (2011). Whole grain rye bread. Retrieved from European Food Information web site: http://ebasis.eurofir.org

6. Fineli. (2010). Foods. Retrieved from Finnish Food Composition database: http://www.fineli. fi/index.php?lang=en

7. Hagg, M., \& Kumpulainen, J. (2002). Thiamine and riboflavin contents of Finnish breads and their corresponding flours. Journal of Food Composition and Analysis, 7, 94-101.

8. Hakansson, B., \& Jagerstad, M. (1990). The effect of thermal inactivation of lipoxygenase on the stability of vitamin E in wheat. Journal of Cereal Science, 12, 177-185.

9. Hiller, B., Schlormann, W., Glei, M., \& Lindhauer, M.G. (2011). Comparative study of colorectal health related compounds in different types of bread: Analysis of bread samples pre and post digestion in batch fermentation model of the human intestine. Food Chemistry, 125, 1202-1212.

10. Khetarpaul, N., \& Chauhan, B.M. (1989). Effect of fermentation on protein, fat, minerals and thiamine content of pearl-millet. Plant Foods for Human Nutrition, 39, 169-177.

11. Kunkulberga, D., \& Segliņš, V. (2010). Maizes ražošanas tehnolog̣ija. Rīga: RTU izdevniecība.

12. Lextinen, P., Kaukovirta-Norja, A., \& Poutanen, K. (2009). Rye and oats - innovative processing and ingredients. Retrieved from 
http://www.aaccnet.org/cerealfoodsworld/pdfs/ CFW-54-2-suppl.pdf.

13. Lindhauer, M.G. (2008). Anti-oxidative potential of breads in dependence on recipees and baking procedure. In Proceedings of 4th International Congress "Flour - Bread '07" (pp. 50-57). Osijek, Croatia.

14. Liu, S., Manson, J.A., Stampfer, M., Hu, F., Giovannucci, E., Colditz, G., ... Willett, W. (2000). A prospective study of whole-grain intake and risk of type- 2 diabetes mellitus in women. American Journal of Public Health, 90, 1409-1415.

15. Liukkonen, K.H., Katina, K., Wilhelmsson, A., Myllymaki, O., Lampi, A.M., Kariluoto, S., ... Poutanen, K. (2003). Process-induced changes on bioactive compounds in whole grain rye. Proceedings of the Nutrition Society, 62, 609-619.

16. LR CSP (2010). Latvijas statistikas gadagrāmata 2009. Rīga: LSP.

17. LR Veselības Ministrija. (2008). Ieteicamās energijas un uzturvielu devas Latvijas iedzìvotājiem. Retrieved from http://phoebe. vm.gov.lv/misc_db/web.nsf/626e6035eadbb4cd 85256499006b15a6/195448bbbf7b0975c22573 13001f19e0/\$FILE/IEUD_300908.pdf

18. Martinez-Villaluenga, C., Horszwald, A., Frias, J., Piskula, M., Vidal-Valverde, C., \& Zielinski, H. (2009). Effect of flour extraction rate and baking process on vitamin $\mathrm{B}_{1}$ and $\mathrm{B}_{2}$ contents and antioxidant activity of gingerbased products. European Food Research \& Technology, 230, 119-124.

19. Mihhalevski, A., Nisamedtinov, I., Halvin, K., Ošeka, A., \& Paalme, T. (2013). Stability of B-complex vitamins and dietary fiber during rye sourdough bread production. Journal of Cereal Science, 57, 30-38.

20. Montonen, J., Jarvinen, R., Heliovaara, M., Reunanen, A., Aromaa, A., \& Knekt, P. (2005). Food consumption and the incidence of type II diabetes mellitus.
European Journal of Clinical Nutrition, 59, 441-448.

21. Montonen, J., Knekt, P., Jarvinen, R., Aromaa, A., \& Reunanen, A. (2003). Whole-grain and fiber intake and the incidence of type 2 diabetes. American Journal of Clinical Nutrition, 77, 622-629.

22. Nystrom, L., Lampi, A., Andersson, A., Kamal-Eldin, A., Gebruers, K., Courtin, C., ... Piironen, V. (2008). Phytochemicals and dietary fiber components in rye varieties in the HEALTHGRAIN diversity screen. Journal of Agricultural and Food Chemistry, 56, 9758-9766.

23. Parikka, K., Rowland, I.R., Welch, R.W., \& Wahala, K. (2006). In vitro antioxidant activity and antigenotoxicity of 5-n-alkylresorcinols. Journal of Agricultural and Food Chemistry, 54, 1646-1650.

24. Poutanen, K. (1997). Rye bread: Added value in the world's bread basket. Cereal Foods World, 42, 682-683.

25. Rakčejeva, T. (2006). Biologiski aktivēti graudi kviešu maizes ražošanā. Promocijas darbs inženierzinātņu doktora zinātniskā grāda iegūšanai pārtikas zinātnē, LLU, Jelgava.

26. Schatzkin, A., Lanza, E., Corle, D., Lance, P., Iber, F., Caan, B., ... Slattery, M. (2000). Lack of effect of a low-fat, high-fiber diet on the recurrence of colorectal adenomas. New England Journal of Medicine, 342, 1149-1155.

27. Seal, C.J. (2006). Whole grains and CVD risk. Proceedings of the Nutrition Society, 65, 24-34.

28. Ward, J., Poutanen, K., Gebruers, K., Piironen, V., Lampi, A.-M., Nystrom, L., ... Shewry, P. R. (2008). The HEALTHGRAIN cereal diversity screen: Concept, results and prospects. Journal of Agricultural and Food Chemistry, 56, 96999709.

29. Wennermark, B., \& Jagerstad, M. (1992). Bread making and storage of various wheat fractions affect vitamin E. Journal of Food Science, 57(5), 1205-1209.

\section{Pateicība}

Pētījums veikts ar ESF projekta „Atbalsts doktora studiju programmu īstenošanai”, vienošanās Nr. 2009/0180/1DP/1.1.2.1.2/09/IPIA/VIAA/017/, lïguma Nr. 04.4-08/EF2.PD.32, atbalstu. 